\title{
ACCOUNTING FOR TRASH MANAGEMENT AT UNIVERSITI MALAYSIA TERENGGANU
}

\author{
NUR AQILAH AWANG NASRAN, SHAYUTI MOHAMED ADNAN*',FATIMAH \\ SHAHMAN AND SITI HAJAR ZAWAWI
}

Universiti Malaysia Terengganu, 21030 Kuala Nerus, Terengganu, Malaysia

*Corresponding author: shayuti.adnan@umt.edu.my

\begin{abstract}
This paper provides preliminary evidence of the need for accounting for trash management in public organizations, in particular, Universiti Malaysia Terengganu (UMT). It has two objectives: to solicit opinions from students regarding their behaviors and perceptions towards recycling habits, and to provide data on the extent of accounting for trash management at UMT. A survey among 155 UMT students indicated that they recycled the trash and were aware of environmental issues caused by the waste. However, they were not informed about the benefits of environmental management accounting practice particularly regarding trash management. Interviews with UMT management also revealed that while UMT supported recycling activities by funding the projects and providing facilities, the data on the opportunity cost involved in the current practice was never integrated into UMT accounting system. As a result, the management had no idea of how much was lost (or gained) during the process. Based on the findings, this study calls for the implementation of accounting for trash management in a public university.
\end{abstract}

Keywords: Trash, environmental management accounting (EMA), policy, UMT, recycle

\section{Introduction}

Waste is one of the major environmental problems in Malaysia. Generally, waste can be divided into two types: recyclable and nonrecyclable items. The waste problem occurs due to the increase in Malaysia's population rate. A study documented that an increment in Malaysia's population rate affects the quantity of waste produced by Malaysians per day. Approximately 33,000 tonnes of waste was produced per day in 2014 compared to 22,000 tonnes in 2012. The waste, in addition to creating problems such as odor and pests, affects the shape of landfills in Malaysia, as landfills are used as the main method of waste disposal.

Therefore, the Malaysian government has set up several policies and plans regarding waste management in Malaysia, such as the action plan for a Beautiful and Clean Malaysia policy (ABC), National Strategic Plan for Solid Waste Management, Master Plan on National Waste Minimization and Act 672 of Laws of Malaysia (Solid Waste and Public Cleansing Management Act) that came into effect in 2011. It can be synthesized in general that the main objective of the policies and plans is to minimize the quantity of waste through activities of reduce, re-use and recycle (3R). However, the success of waste minimization can be achieved through participation from various parties such as the public sectors and the government, and the willingness of the public to support the government policies.

According to Samsudin, M. D., \& Don, M. M., 2013, the public's willingness to cooperate and participate in waste management is 
influenced by their awareness; thus, lack of awareness and knowledge negatively affects solid waste management practice in Malaysia, particularly in relation to $3 \mathrm{R}$ activities (Samsudin, M. D., \& Don, M. M., 2013 ; Ramayah, T., \& Rahbar, E., 2013). As such, improving Malaysian awareness should be a priority (Samsudin, M. D., \& Don, M. M., 2013).

On the other hand, accounting number plays a crucial role in addressing waste issue. One of the mechanisms is through the implementation of environmental management accounting (EMA). In EMA, the accounting itself is not limited to monetary information but also emphasizes on physical non-monetary information. The availability of both types of information will help companies to understand cost behavior of the waste and subsequently implement the right strategies to reduce waste while maximizing profit.

Accordingly, this paper examines the extent of EMA practice at Universiti Malaysia Terengganu (UMT) and solicits students' opinions regarding their behaviors and perceptions towards recycling habits. In addition, it provides a preliminary analysis on the opportunity costs for involving in recycling activities.

\section{Literature Review \\ Environmental Management Accounting (EMA)}

Nowadays, environmental management accounting (EMA) is documented as a solution to reduce the global environmental problems especially waste issues. Basically, EMA has similarities with conventional accounting because EMA processes also consist of identification, collection and analysis of accounting information. Nevertheless, the types of information used in EMA cover a wider scope than conventional accounting. In conventional accounting, the monetary information is the only information used in preparing the financial statements. However, in EMA, there are two main types of information used in preparing financial statements, namely physical and monetary information. Physical information, also known as indirect information, is information that cannot be approximated, such as flow and rate of water and materials.

EMA is not limited to manufacturing industries but can be adopted by various industries including learning institutions. However, at learning institutions such as universities, EMA has not received interest and attention because universities generate environmental impact lesser than that of manufacturing industries (Chang, H., 2013). For example, in a study of EMA at higher education sector, the findings revealed that the extent of EMA practices at higher education institutions was still lacking. There was generally an absence of accounting system designed and highlighted to examine the potential uses and applications of EMA at higher education sector (Chang, H., 2013).

EMA is not only a tool to reduce waste issues, but it also gives benefits to individuals. As mentioned earlier, indirect information is one of the elements used in preparing EMA financial statements. As stated by Qian, W., Burritt, R., \& Monroe, G. (2011), indirect costs can easily be overlooked, which has caused many cost saving opportunities to be missed. The findings of Qian, W., Burritt, R., \& Monroe, G., 2011 also revealed that individuals used to ignore the disposal cost via recycling. Therefore, education regarding waste and recycling is a crucial mechanism to improve recycling qualities.

In another study, the findings of Jalaludin, D., Sulaiman, M., \& Ahmad, N. N. (2011) disclosed that the adoption of EMA in Malaysia was still at low level and that accountants did not participate much in environmental system. It was also acknowledged that there was lack of knowledge regarding the adoption of EMA in developing countries. In addition, educational background, trainings and adoptions of 
companies' policy influence the adoption of EMA in companies in Malaysia.

\section{Attitude and Behavior towards Trash Management}

This study posited a similar argument with prior studies that recycling activities were seen as an environmental friendly approach to solving waste problems and to save landfill space and disposal costs (Qian, W., Burritt, R., \& Monroe, G., 2011). The 3R initiative as a waste management in higher education sector had positive effects on the campus community (Tangwanichagapong, S., Nitivattananon, V., Mohanty, B., \& Visvanathan, C. 2017). However, the willingness to cooperate and participate in waste management depended on awareness and attitude of people within the organizations of a country (Samsudin, M. D., \& Don, M. M., (2013).

\section{Research Questions and Methodology}

This study has two objectives: to investigate the extent of EMA practice in Universiti Malaysia Terengganu and to examine students' behaviors towards waste management. The first objective was achieved through a face-toface interview with staffs handling trash at UMT management level. In addition, an activity of selling trash was conducted to determine how much of opportunity cost was lost in foregoing the selling of trash activities in the university. The second objective was achieved through a questionnaire survey of 155 students at various faculties in UMT. Figure 1 presents the research questions, objectives and methodology.

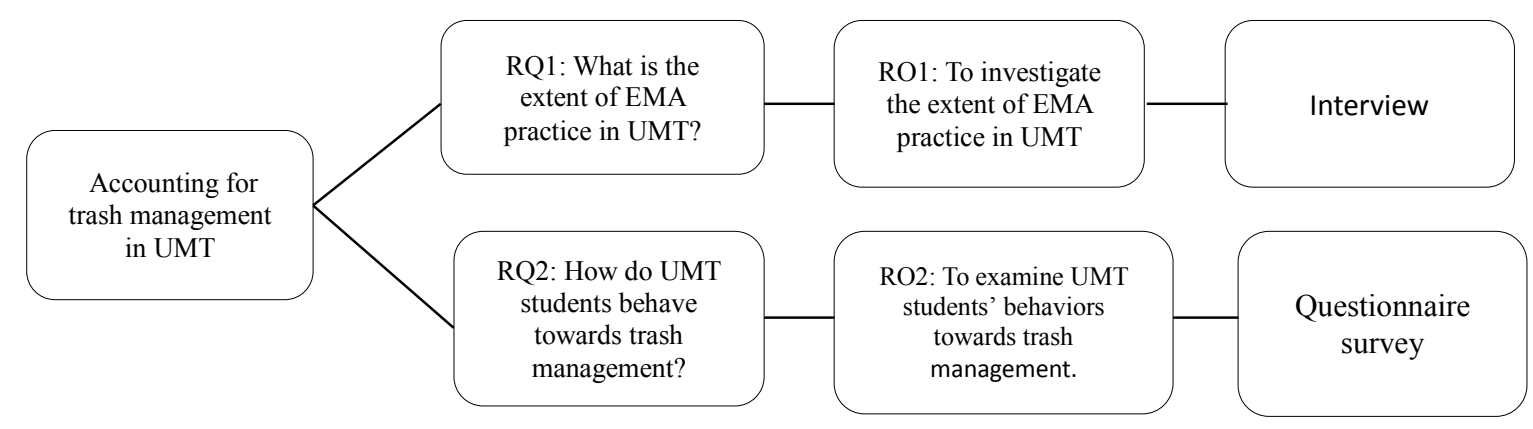

Figure 1: The framework of methodology

\section{The Interview}

The interview session was conducted with a staff from the Property Management and Development Centre. The purpose of the interview was to discover the extent of EMA practices in UMT, including the availability of monetary and physical information from waste management processes, policy regarding waste segregation and recycling activities as EMA practices in UMT.

\section{Questionnaire Survey}

The questionnaire survey solicited attributes including awareness, intention and behavior towards waste management practices; recycling facilities provided by UMT; ideologies towards recycling behavior and awareness of EMA practices.

The questionnaire consisted of four sections: A, B, C and D. Section A asked questions pertaining to the respondent's demographic information such as age, address, gender, faculty, program, year of study, race and whether the student enrolled in any environmental subject(s). Section B solicited information on student's knowledge, behavior and attitude towards environmental issues, particularly in term of waste management and recycling. Section $\mathrm{C}$ was about recycling 
facilities and ideology. This section examined whether the students perceived that UMT had sufficient recycling facilities, the waste management policy was related to $3 \mathrm{R}$ activities, and the students' ideologies regarding waste management could influence the recycling behaviors among UMT students. The final section, section $\mathrm{D}$, asked about environmental management accounting (EMA). Respondents answered if they understood the concept of EMA, its benefits and whether they agreed that UMT should practice EMA in its accounting system.

The answers were in likert-item scales ranging from 1 (strongly disagree) to 5 (strongly agree). This study used the descriptive statistics as an analysis tool to analyse the results. In total, 200 questionnaire surveys were distributed; however, only 155 students returned the completed surveys.

\section{Results and Discussion \\ The extent of EMA practices at UMT}

The face-to-face interview session with the officer revealed that UMT has not yet adopted EMA with regard to waste management simply because the university uses a 'contract-based' method for managing the waste. The method involves outsourcing trash management activities to a contractor, and all trash-related activities are under the responsibility of the contractor. The staff further mentioned that there no information (neither physical nor monetary) has been recorded, as the university only estimates the waste management costs involving waste collection, storage, transport and waste disposal based on agreed contract price for the outsourced project. The recyclable and non-recyclable items are referred to as domestic waste. The domestic waste is collected by the contractor at defined zones around $10.00 \mathrm{am}-6.00 \mathrm{pm}$ and will be disposed at a landfill at $\mathrm{Kg}$ Sungai Ikan.
From an EMA perspective, UMT is still lacking in terms of its awareness of EMA adoption and therefore it does not integrate any information which is deemed useful to the top management. Only the monetary element (cost of contracts) is recorded in UMT system while the physical information is considered unnecessary, regardless of previous studies' findings that stated that EMA can help reduce the environmental issues, costs and may be profitable. Indirect benefit is one of the factors that causes physical information to be easily overlooked. In this case, the creation of a new policy is mandatory as it can have a significant role in inspiring the adoption of EMA.

From UMT perspective, the waste segregation as a policy is unsuitable. The university has constraints in resources including workers' capacity. Therefore, waste segregation has not become a priority in policy setting. In addition, the benefits of EMA are still not clearly portrayed in the management agenda. The utmost priority is placed on building cleanliness rather than waste segregation. The interview session revealed that, although waste segregation is not a priority for UMT due to constraint in workers' capacity, UMT is supportive of any recycling activities organized by student clubs and faculties. The university does provide recycling facilities, and fund students' projects related to minimization of environmental hazard activities.

\section{Attitude and Behavior towards Trash Management}

The attitude and behavior towards trash management was assessed in terms of awareness of environmental issues, behavior towards recycling activities, intention to recycle, existence of recycling facilities and knowledge about EMA. 


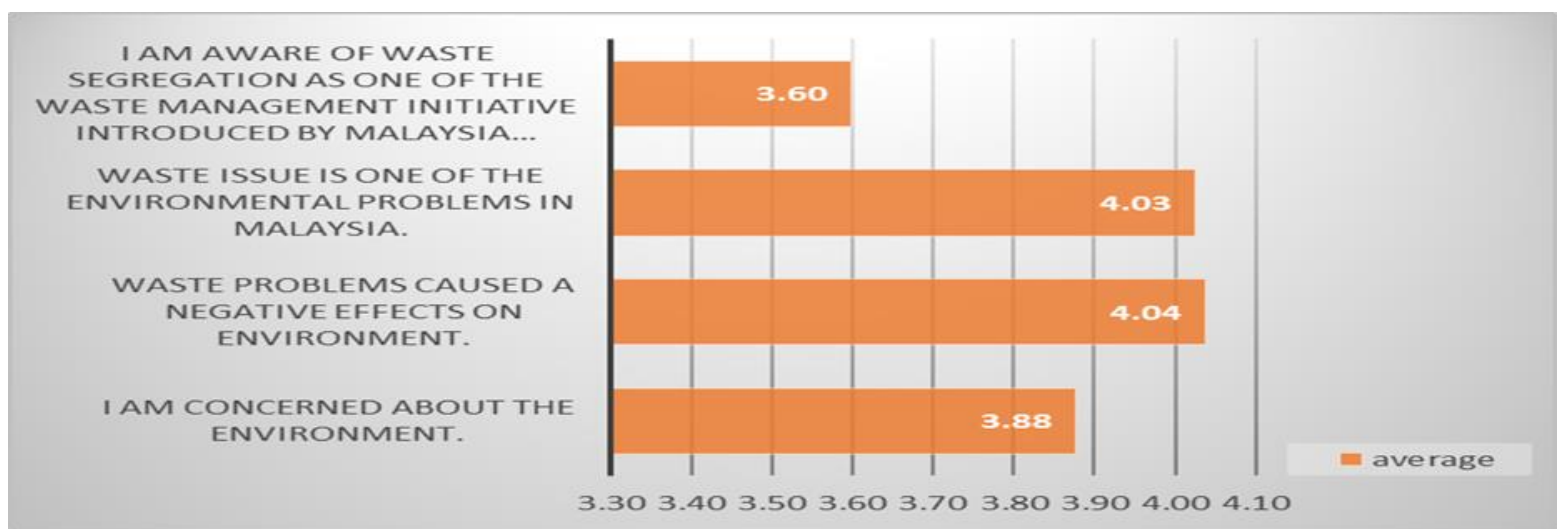

Figure 2: Student's awareness towards environmental issues (\%)

Figure 2 presents the descriptive results of the acknowledged that waste was one of the questionnaire survey. It shows that UMT students were aware of the environmental issues encountered in Malaysia and environmental issues. They also agreed that waste segregation was one of the government's initiatives to reduce the environmental issues.

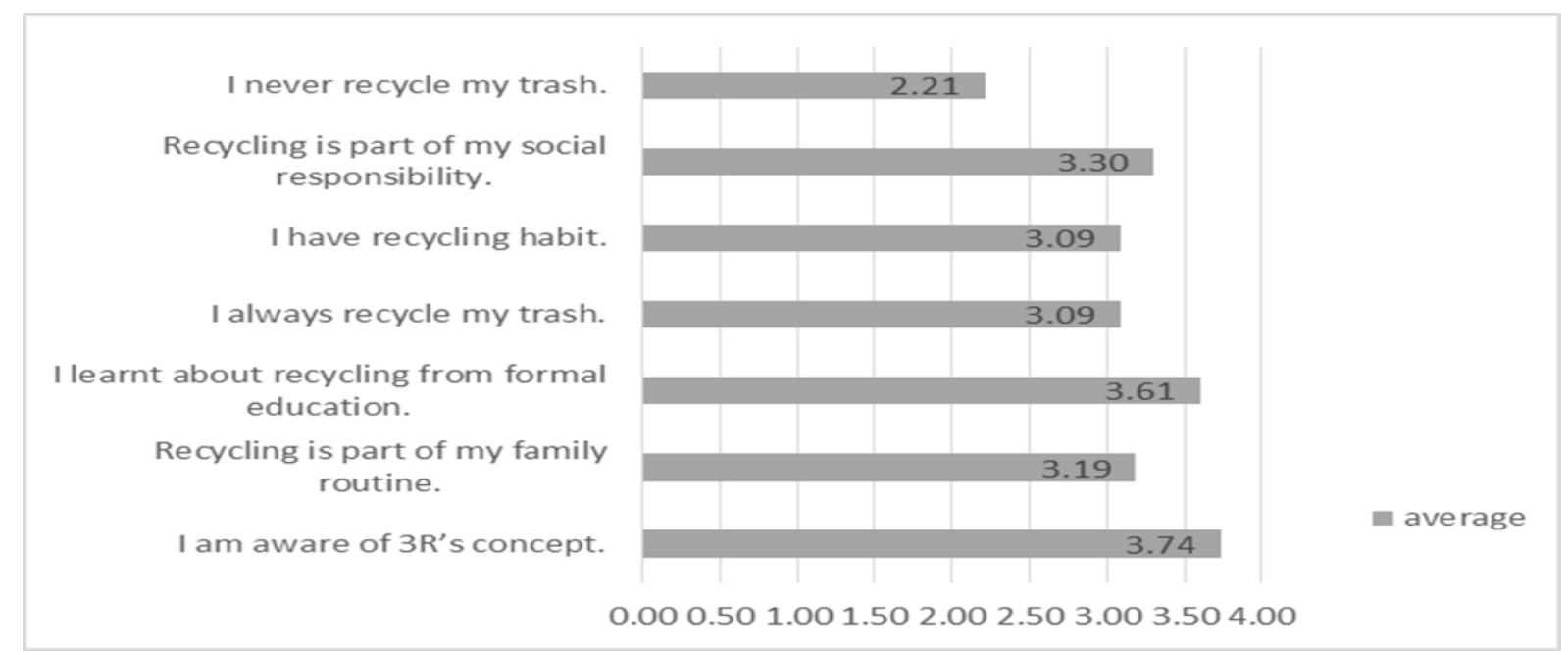

Figure 3: Responses regarding student's recycling behavior

Figure 3 reveals that majority of the students were aware of the $3 R$ s concepts and received a formal education regarding recycling activities. They also assumed that recycling was part of their responsibility. Furthermore, the students were of the opinion that recycling was part of their family routine. 


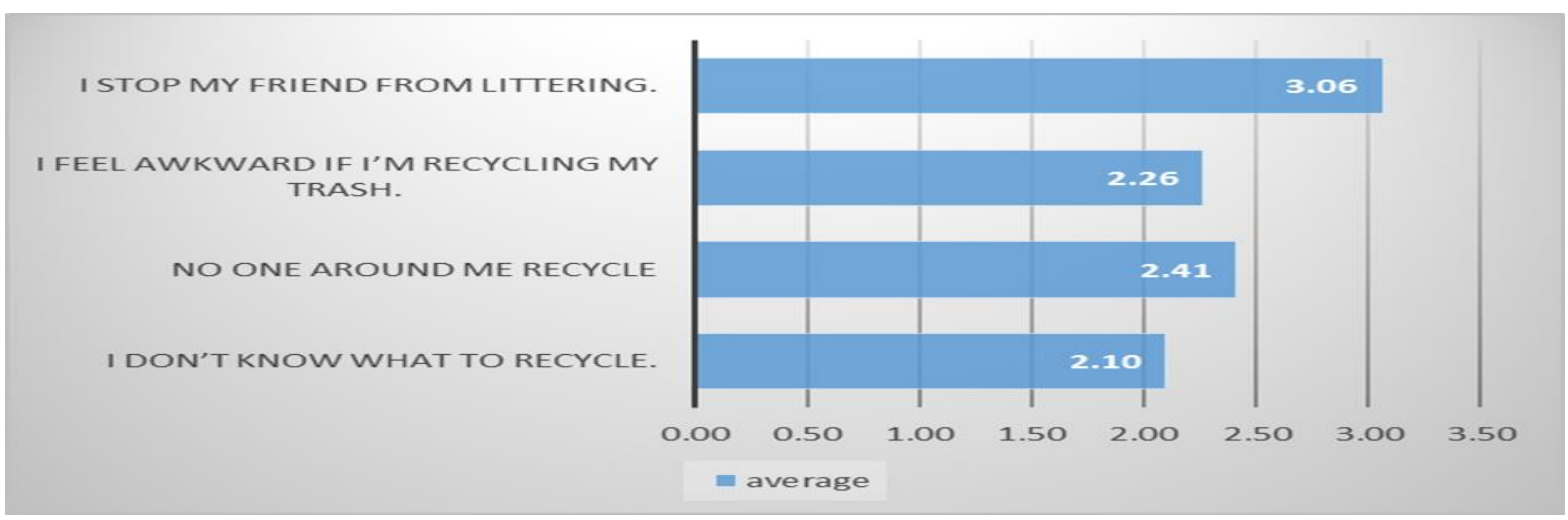

Figure 4:Responses regarding student's intention to recycle

Figure 4 presents students' intention to recycle. students knew what to recycle (reverse coded) The results indicate a positive behavior toward and they did not feel awkward recycling the recycling activities. The figure shows that recyclable items.

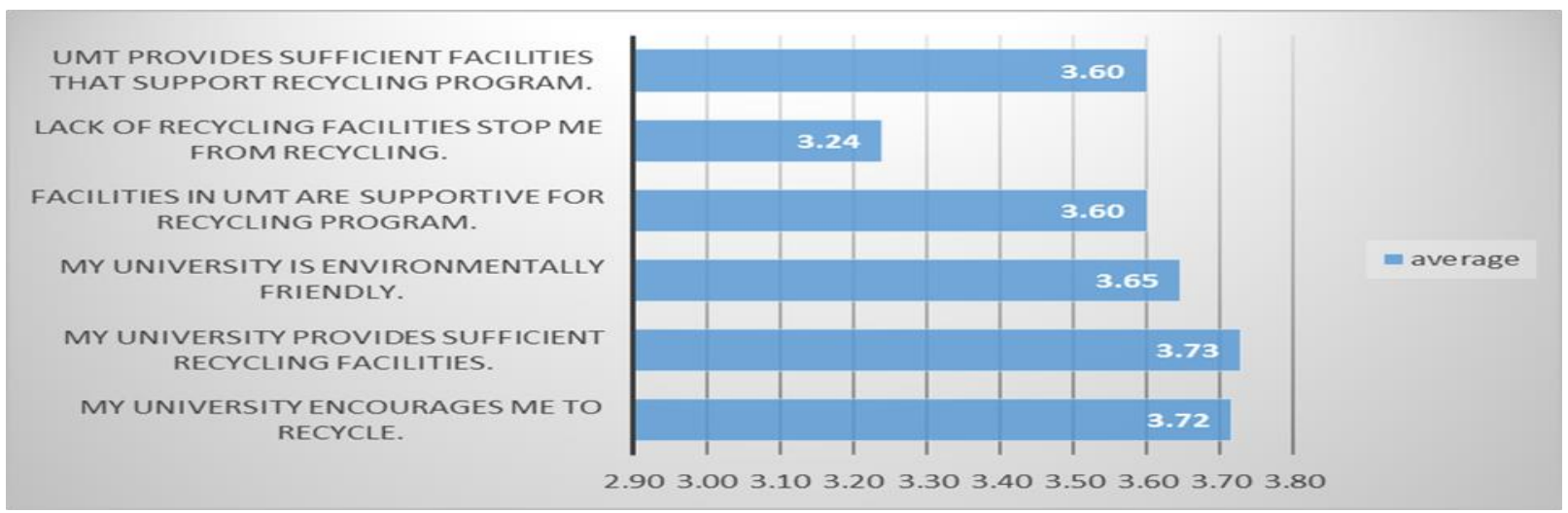

Figure 5. Responses regarding recycling facilities at UMT

Figure 5 shows the perceptions of students regarding recycling activities at UMT. The results supported the findings from the interview, where UMT students agreed that the university provides sufficient recycling facilities. Furthermore, students also acknowledged that UMT encourages them to recycle their waste. Lack of recycling facilities does not stop students from recycling their items.

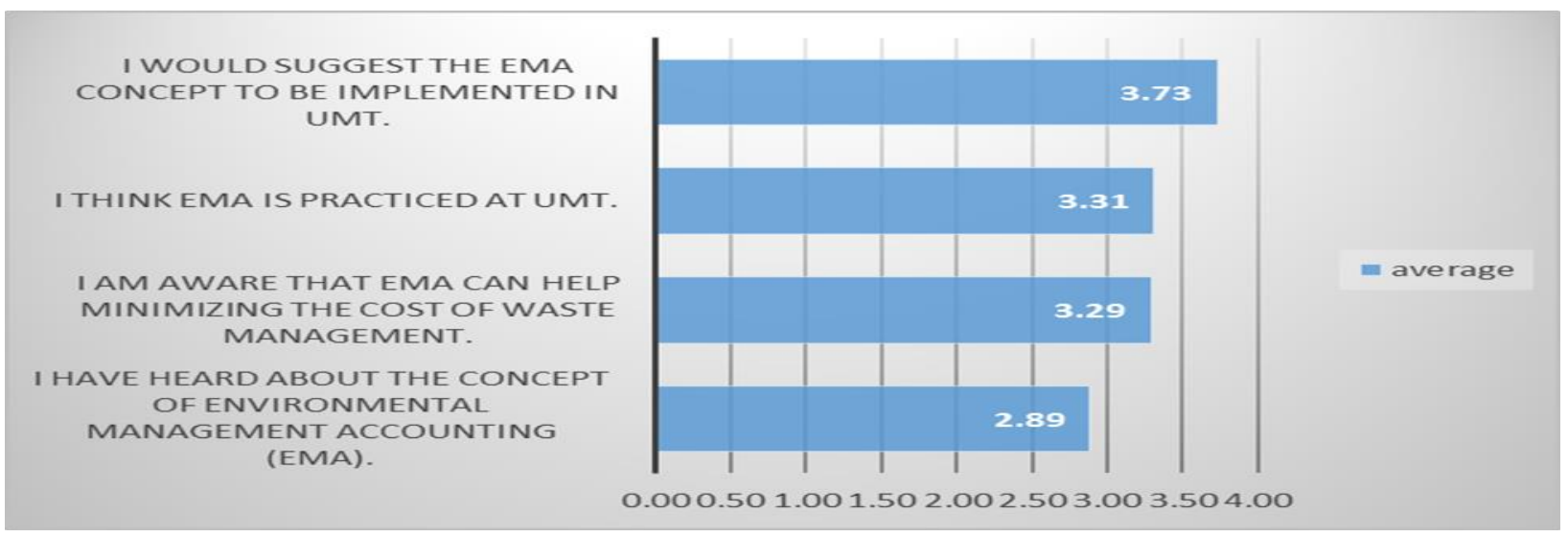

Figure 6. Responses regarding EMA concept

Figure 6 presents the students' responses shows that EMA was not common among regarding their awareness of EMA concept. It UMT students. The results are plausible

Universiti Malaysia Terengganu Journal of Undergraduate Research

Volume 1 Number 3, Julai 2019: 36-45 
because respondents do not have accounting background. Interestingly, accounting students and non-accounting students were similar in terms of their unawareness of the benefits of EMA. However, there was a general agreement among the students for the implementation of EMA concepts at UMT. They also believed that EMA could help minimize the cost of waste management.

\section{Discussions}

The results indicated that the extent of EMA practices at UMT is still at low level, and there is a lack of awareness regarding waste management as UMT relies on a contractor to manage waste in the campus. Thus, the monetary and non-monetary information pertaining to the waste management is nonexistent. The results are consistent with Huei (2013) and Jalaludin et al. (2011), which disclosed that lack of environmental accountability and information are barriers to EMA implementation in higher education institutions. However, the policy makers have a significant role in inspiring the adoption of EMA (Jalaludin et al. 2011).

In UMT, the implementation of EMA especially with regard to trash management is possible because students' recycling behavior, their attitudes and intention towards recycling activities are complemented by the facilities provided by UMT. The university itself is viewed as environmentally friendly institution and it supports many recycling activities by funding various students' projects. For example, one of the projects is The Bank-in Trash programme that was held at the School of Maritime Business and Management. The project collected papers in a period of one month and quantified the amount of trash in both monetary and physical aspects. Most of the trash collected were papers (examinations, assignment and test papers) and plastic drinking bottles. In a period of one month, the project managed to collect $700 \mathrm{~kg}$ of papers with the cost of RM181 (Figure 7). If this amount was consistent throughout the year, it can be estimated that one faculty could have a revenue loss of RM2,172 per year (RM181 x 12 months). The amount would increase to approximately RM20,000-RM30,000 per year for all faculties and institutions in the university. This amount is sufficient to sponsor two internal research projects. For future study, it is suggested that the focus should be on analyzing how much UMT spends on buying papers for the purpose of research and education. 
Table 1. The revenue of the Bank-in Trash program

\begin{tabular}{lcr}
\hline \multicolumn{1}{c}{ Recycable items } & Quantity & RM (Revenue) \\
\hline Papers & & \\
RM 0.20 per kg/colour & $250 \mathrm{~kg}$ & 50.00 \\
RM 0.30 per kg/white & $450 \mathrm{~kg}$ & 135.00 \\
File & & \\
RM 0.10 per kg & $2.5 \mathrm{~kg}$ & 0.25 \\
Wire & & \\
RM 1.50 per wire & 1 & 2.50 \\
Others & $76.5 \mathrm{~kg}$ & 20.10 \\
Total Revenue & & 2.85 \\
\hline
\end{tabular}

\section{Conclusion}

The findings showed that UMT does not adopt EMA practices and does not have any specific policy regarding waste management. The waste management of UMT is outsourced so accounting information pertaining to waste is forgone. Although UMT students have positive attitudes and intention to recycle, voluntaryapproach alone is insufficient to ensure that waste management activities work effectively. Accordingly, the study calls for the implementation of a university management policy related to recycling activities.

The EMA practice in the current study should be interpreted in light of three limitations. First, it focused only on the recycling activities at UMT and second, its scope was limited to landfill waste only. It discarded other aspects of EMA such as on carbon dioxide management, energy usage and landfill waste other than papers and nonrecycled items. Finally, the study inherited a common weaknesses in perception study conducted through questionnaire survey. Future research may be extended to other institutions and cover scopes omitted in this research.

\section{Acknowledgements}

The authors acknowledge PPPPM for its supports in the Bank-in Trash Programme. The authors would also like to thank the editors for their helpful assistance throughout the preparation of this manuscript.

\section{References}

Abas, M. A., \& Wee, S. T. (2014). Municipal Solid Waste Management in Malaysia: An Insight Towards Sustainability. SSRN Electronic doi: $10.2139 /$ ssrn. 2714755

Journal.

ACCA. (2017). Environmental management accounting. Retrieved from http://www.accaglobal.com/my/en/student/e xam-support-resources/professional-examsstudy-resources/p5/technicalarticles/environmenta-management.html, 31 December 2017.

Ajzen, I. (1991). The theory of planned behavior. Organizational behavior and human decision processes, 50(2), 179-211. 
Chang, H. (2013). Environmental management accounting in the Taiwanese higher education sector. International Journal of Sustainability in Higher Education, 14(2), 133-145. doi:10.1108/14676371311312851

Chartered Global Management Accountant. (2017) Environmental Management Accounting. Retrieved from https://www.cgma.org/resources/tools/costtransformation-model/environmentalmanagement-accounting.html, 31 December 2017.

Cole, E. J., \& Fieselman, L. (2013). A community- based social marketing campaign at Pacific University Oregon. International Journal of Sustainability in Higher Education, 14(2), 176-195. doi:10.1108/14676371311312888

Dempsey, M. E., \& Palilonis, A. (2012). Reuse, recycle... reduce: a greener library with print management. Library $\mathrm{Hi}$ Tech, 30(3), 408-417

Ferreira, A., Moulang, C., \& Hendro, B. (2010). Environmental management accounting and innovation: an exploratory analysis. Accounting, Auditing \& Accountability Journal, 23(7), 920-948. doi:10.1108/09513571011080180

Fisher, R. M. (2003). Applying ISO 14001 as a business tool for campus sustainability. International Journal of Sustainability in Higher Education, 4(2), 138-150. doi:10.1108/14676370310467159

Jalaludin, D., Sulaiman, M., \& Ahmad, N. N. (2011). Understanding environmental management accounting (EMA) adoption: a new institutional sociology perspective. Social Responsibility Journal, 7(4), 540-557. doi:10.1108/17471111111175128

Letmathe, P., \& Doost, R. K. (2000). Environmental cost accounting and auditing. Managerial Auditing Journal, 15(8), 424431. doi:10.1108/0268690001035470
Lima Ribeiro, V. P., Aibar Guzmán, C., da Silva Monteiro, S. M., \& Aibar Guzmán, B. (2012). Determining factors of environmental management practices in Portuguese local entities. Management of Environmental Quality: An International Journal, 23(5), 486-502.

Manaf, L. A., Samah, M. A. A., \& Zukki, N. I. M. (2009). Municipal solid waste management in Malaysia: Practices and challenges. Waste management, 29(11), 2902-2906.

Ministry of Housing and Local Government. (2015). Retrieved from http://www.kpkt.gov.my/separationatsource/ en/, 02 January 2018.

Mistry, V., Sharma, U., \& Low, M. (2014). Management accountants perception of their role in accounting for sustainable development. Pacific Accounting Review, 26(1/2), 112-133. doi:10.1108/par-06-20130052

Qian, W., Burritt, R., \& Chen, J. (2015). The potential for environmental management accounting development in China. Journal of Accounting \& Organizational Change, 11(3), 406-428. doi:10.1108/jaoc-11-20130092

Qian, W., Burritt, R., \& Monroe, G. (2011). Environmental management accounting in local government. Accounting, Auditing \& Accountability Journal, 24(1), 93-128. doi:10.1108/09513571111098072

Ramayah, T., \& Rahbar, E. (2013). Greening the environment through recycling: an empirical study. Management of Environmental Quality: An International Journal, 24(6), 782-801. doi:10.1108/meq07-2012-0054

Samsudina, M. D. M., \& Dona, M. M. (2013). Municipal solid waste management in Malaysia: Current practices, challenges and prospect. Hospital, 17, 0-9. 
Skanavis, C., \& Sarri, E. (2002). The role of environmental education as a tool for environmental management in Cyprus. Environmental Management and Health, 13(5), 529-544. doi:10.1108/09566160210441816

Tangwanichagapong, S., Nitivattananon, V., Mohanty, B., \& Visvanathan, C. (2017). Greening of a campus through waste managementinitiatives. International Journal of Sustainability in Higher Education, 18(2), 203-217. doi:10.1108/ijshe-10-2015-0175

Wan, C., Cheung, R., \& Qiping Shen, G. (2012). Recycling attitude and behaviour in university campus: a case study in Hong Kong. Facilities, 30(13/14), 630-646. 